\title{
Türkiye'de Bir Büyükşehirdeki Okullarda Gürültü Seviyesinin Tespiti ve Öğretmenlerin Görüşlerinin Veri Madenciliği ile Analizi
}

\author{
Âli Yurdun ORBAK ${ }^{1}$ ve Fikret Umut AYDIN ${ }^{2}$
}

Öz

Sınıf içi gürültü öğrencilerin işlenen dersleri anlayabilmesini ve öğretmenle iletişim kurmasını zorlaştırmaktadır. Bir okuldaki gürültü düzeyi okulun eğitim kalitesini etkileyen başlıca parametrelerden birisidir. Okul binası içindeki gürültü öğrencilerin yanı sıra öğretmen, idareci ve memurların hem performansını hem de sağlığını olumsuz yönde etkilemektedir. Bu çalışmada Türkiye'de bir büyükşehir ve sanayi şehri olan Bursa ilindeki farklı lokasyonlardaki dört okulda akustik yalıtımın ne düzeyde olduğu araştırılmıştır. Bu amaçla seçilen okullarda gürültü ve çınlanım ölçümleri yapılmıştır. Gürültü ölçümleri derste sınıf ve koridorda, teneffüste sınıf ve koridorda olacak şekilde 4 farklı durumda yapılmıştır. Gürültü ölçümleri Dünya Sağlık Örgütü’nün belirlediği 55 dB olan okullardaki gürültü sınırı ile ve ayrıca Türkiye Cumhuriyeti Çevre Şehircilik Bakanlı̆̆ı’nın Binaların Gürültüye Karşı Korunması Hakkında Yönetmeliğ̣i ile kıyaslanmış, analizler için MINITAB ve Brüel \& Kjaer Measurement Partner Suite programları kullanılmıştır. Ölçüm sonuçlarına göre sınıflardaki gürültü seviyesinin hem uluslararası ve hem de ulusal sınırların üzerinde olduğu ve mevcut yalıtımın yetersiz kaldığı saptanmıştır. Çınlanım süresinin düşürülebilmesi için sınıfların akustik ses emici özelliği olan malzemeden yapılmış panolarla iyileştirilmesi, gürültü emici panellerle sınıf ve koridor tavanlarını kaplatılması gibi başlıca akustik önlemler alınmalıdır. Öğretmenlere yapılan anketlerin Apriori ile analizi sayesinde okullar arasında gürültü algısı açısından bir fark olmadığı ve bütün öğretmenlerin gürültü konusunda rahatsızlıkları olduğu saptanmıştır.

Anahtar Kelimeler: Gürültü kirliliği, Çınlanım gürültü analizi, Gürültü eğitimi

Assessment of Noise Level of Several Schools in a Big City in Turkey and Analysis of Teacher's Opinions Using Data Mining Technique

\begin{abstract}
Noise in the classroom makes it harder to follow the lesson and communication with the teacher. The noise level in school is one of the main parameters that affect the quality of education. Noise in school influences the health and performance of teachers, administrators, officers as well as students. In this study, the investigation of acoustic insulation level of four schools in different locations was conducted in Turkey's metropolitan and industrial city of Bursa. Noise and reverberation measurements were made in schools which were selected for this purpose. Noise measurements were made with four different situations, in classrooms and corridors during course hours and during breaks. Noise measurements were compared with limit values which are determined by World Health Organization $(55 \mathrm{~dB})$ and noise regulation of Republic of Turkey Ministry of Environment and Urbanization, and also MINITAB 17 and Brüel \& Kjaer Measurement Partner Suite programs were used for analysis. According to the measurement results, it was found that the noise level in the classes was above both international and national limit values and the existing insulation was insufficient. In order to reduce the reverberation time, the main acoustic measures should be taken, such as improving classes by panels that are made of acoustic sound absorbing materials, and the covering of the class and corridor ceilings with noise absorbing panels. Through Apriori analysis of teacher's surveys, it was obtained that there was no difference between the schools in terms of noise perception and all teachers were disturbed by the noise.
\end{abstract}

Key Words: Noise pollution, Reverberation noise analysis, Noise education

Atıf İçin / Please Cite As:

Orbak, A. Y. ve Aydın, F. U. (2020). Türkiye'de bir büyükşehirdeki okullarda gürültü seviyesinin tespiti ve öğretmenlerin görüşlerinin veri madenciliği ile analizi. Manas Sosyal Araștırmalar Dergisi, 9(3), 1375-1390.

Geliş Tarihi / Received Date: 24.04.2019

Kabul Tarihi / Accepted Date: 02.05.2020

\footnotetext{
1 Doç. Dr. - Bursa Uludağ Üniversitesi, Mühendislik Fakültesi, Endüstri Mühendisliği Bölümü, orbak@uludag.edu.tr ORCID: 0000-0002-4921-4275

2 Doktora Öğrencisi - Bursa Uludağ Üniversitesi, Fen Bilimleri Enstitüsü, Endüstri Mühendisliği Anabilim Dalı, aydin_umutt@hotmail.com - ORCID: 0000-0001-5797-0217
} 


\section{Giriş}

Türkiye'de çocukların yılda 2.000 saatinin büyük kısmını deneysel temelden yoksun olarak tasarlanmış okul ortamında geçirdikleri göz önünde alındığında, bu şekilde yapılan eğitimin potansiyel etkileri ve bedeli çok derindir. Çünkü sınıfın fiziksel çevresi eğitim-öğretim için kritik öneme sahiptir ve o ortamı soluyan öğrenciler üzerine çok güçlü ve derin izler bırakır. Sınıf ortamının, öğrenmede oynadığı ayrılmaz rolü ilk fark edenlerden birisi 19. yy başlarında Maria Montessori'dir. Montessori'nin eğitim materyallerinin çocuklara sıralama, sınıflama, yap1 ve örüntü gibi kavramları kazandırarak büyüme gelişmelerini desteklediği bilinmektedir. Günümüzde arttk ortamının öğrenme üzerine etkisini inceleyen birçok araştırma bulunmaktadır. Örneğin uygun fiziksel çevrede okula devam eden çocukların okuma, dinleme, dil gelişimi ve matematikte anlamlı olarak daha başarılı olduklarının tespit edildiği bulunmuştur (Bowers ve Burkett, 1987).

Fiziksel çevrenin öğrenmeye etkisi iki kurama dayanmaktadır. Birincisi uyarıcı girişi seviyesinin tepki seviyesi çıkışını kapsayan ilk kuramdır. Buna göre uyarıcı girişinin artmasının buna denk bir tepki çıkışı artışılla sonuçlanacağını varsaymaktadır (Strauss ve Lehtinen, 1947). Genel olarak davranışçı öğrenme modeline dayanan bu kuram günümüzde yerini optimal düzeyde uyarılma kuramına bırakmışıtır. Optimal düzeyde uyarılma kuramına göre çevredeki dış uyarıcıların miktarı çocuğun fizyolojik, dikkat ile ilişkili ve davranışsal tepkisiyle bağdaştırılmalıdır. Buna göre bireylerin, çevresel faktörler dalgalandığı takdirde sabit tutmak için çabalayacakları biyolojik olarak belirlenmiş optimal seviye uyarıcıları bulunmaktadır (Hardiman, 2003). Bu nedenle organizma, yeterli uyarım olmadığında, heyecan arayıc1 aktiviteler başlatacak, çok fazla uyarıcı veya uyarıma maruz kaldığındaysa aktivitelerini kısıtlandırıp uyarıcılardan kaçınacaktır (Berlyne, 1960; Hebb, 1955; McClelland, vd., 1953).Burada öğrenme ortamının aydınlatma, akustik ve düzen açısından dikkatlice planlanmış olması öğrencilerin okula devamı ve disiplinli olmalarına katkı sunmuştur. "Beyin Araştırmalarını Etkili Öğretimle Bütünleştirme" adlı kitabın yazarı Mariale Hardiman’a (2003) göre öğrenmeyi etkileyen fiziksel çevre unsurlarının başında sınıflardaki görsel olarak uyarıcıların çekici olması ve arka plan gürültüsü gelmektedir. Öğrenme ortamı ne kadar ilginç ve güzel görsel materyallerle donattlırsa, ögrrenmenin de o derece artmaktadır. Görsel olarak uyarıcı sınıf ortamı öğrenmeye yardımcı olduğuna göre, aynı durumun işitsel uyarıcılar içinde doğru olacağı düşünülebilir. Her ne kadar çevreden gelen renk, yenilik gibi görsel uyarımların fazla olması genelde olumlu olsa da, işitsel uyarılar için bunun tersi doğrudur. Çünkü görsel uyarıcıların tersine, çocukların işitsel uyarıcı girişini kontrol edemezler. İşitsel uyarının çok fazla olmasının öğrenme üzerine etkileri genelde zararlı olmaktadır (Hardiman, 2003). Ne kadar zararlı etki yaptığı ise: (a) gürültünün seviyesine, (b) gürültüye maruz kalınan süreye, (c) gürültünün ne ölçüde konuşma içerdiğine,(d) uyarımın arttırılmasına katkıda bulunan görevin zorluk derecesi ve (e) öğrenci sayısı gibi çevredeki mevcut diğer uyarıcı etkenlere bağlıdır (Cohen, vd., 1980; Glass ve Singer, 1972; Hockey, 1970; Kryter, 1950).

Türkiye'de ve Dünya'da Okulda gürültü üzerine yapılan birçok araştırma mevcuttur. Ülkemizde yapılan araştırmalar da okulda gürültü kirliliğinin öğrencilerin sağlığını ve akademik başarısını olumsuz yönde etkilediğini göstermektedir (Özbıçakçı vd. , 2012: 230; Polat vd., 2004; Tamer vd., 2011: 175; Tüzel, 2013). Bulunuz (2014) ilköğretim öğrencileri ile yaptı̆̆1 araştırmada, ilk ölçümlerde olduğu gibi son ölçümlerde de bina içinde öğrenci giriş-çıkışı ve teneffüs saatlerinde gürültü düzeylerinin $80-90 \mathrm{~dB}$ aralığında ve oldukça yüksek olduğunu tespit etmiştir. Tamer-Bayazıt, vd.'nin (2011) yapmış olduğu araştırmada okullardaki öğretmenlerin \% 85,2'si okulda gürültünün önlenmesi ya da azaltılmasının eğitimöğretimin kalitesinin yükselmesi için "çok önemli" ve "kritik derecede önemli” olduğunu bulurken, \%11’i ise "önemli" bulmuştur. Özbıçakçı vd. (2012) ilköğretim öğrencileri ile yaptığı bir araştırmada, ölçülen gürültü seviyelerinin öğrencilerin geçici işitme kayıplarına yol açacak düzeyde olduğunu tespit etmiştir. Bulunuz vd. (2017) biri devlet diğeri özel olmak üzere iki İlkokulundaki öğrencilerinin okulda gürültünün hakkındaki görüşlerini değerlendirdiği çalışmada öğrencilerin özellikle teneffüs sırasında ki gürültüyü çok yüksek buldukları sonucuna ulaşılmıştır. Yapılan gürültü ölçümleri de bu veriyi destekler niteliktedir. Özel okulda ortalama gürültü 74,56 dB(A), devlet okulunda ise gürültü düzeyi $82,18 \mathrm{~dB}(\mathrm{~A})$ ölçülmüştür. Yurt dişında yapılan araştırmalarda okullarda yüksek gürültü düzeyi olduğunu ve bunun zararlı etkileri üzerine odaklanmıştır. Örneğin Yassin vd. (2016, s. 2013-2016), Kuveyt'te okullardaki gürültü kirliliğini incelemiş, gürültü ölçümleri ve öğretmenlere anketler yapmıştır. Öğretmenlerin bu gürültüden rahatsız olduğunu tespit ederek gürültünün azaltılması için okullarda yalıtım malzemeleri kullanılmasını önermiştir. Sarantopoulos vd. (2014, s. 496-499), Yunanistan'daki okulların gürültüsünü incelemiş ve trafik gürültüsünün istatistiksel olarak anlamlı bir şekilde okullardaki gürültü seviyesini arttıran faktörlerden birisi olduğunu belirtmiştir. Zannin vd. (2013) Brezilya'da bir üniversitede gürültü kirliliğini ve öğrencilerin bu 
konudaki görüşlerini incelemiş, gürültü haritaları oluşturup en çok gürültülü olan bölgelerde ölçülen veriler ile yapılan anketlerin birbirini desteklediğini, bölgede rahatsız edici düzeyde gürültü olduğu belirtmiştir.

Günümüzde gürültü okulun yanı sıra fabrika, havaalanı, hastaneler, hayvanat bahçesi, doğal parklar gibi birçok alanda araştırma konusu olmaktadır. Merchan vd. (2014), İspanya'da bir tabiat parkındaki gürültü kirliliğini ve ziyaretçilerin bu konudaki görüşlerini incelemiş, gürültü ölçümleri ve ziyaretçilere anketler yapmıştır. Ziyaretçiler bu gürültüden rahatsız olduklarını ve bu gürültünün azaltılması için yapılabilecek bir eğitim için ekonomik destek verebileceklerini belirtmişlerdir. Vasilyev (2017, s. 672), Rusya'nın Samara bölgesindeki gürültüyü incelemiş ve anlık veri akışı sayesinde internet aracilığıla görüntülenebilecek dinamik olarak değişen gürültü haritaları hazırlamıştır. Aktürk vd. (2003, s. 75-79), Ankara'daki kavşakları modelleyerek trafik ışı sürelerinin planlamasının bölgedeki gürültüyü etkilediğini görmüştür. Boateng ve Amedofu (2004, s. 58), Afrika'da bir fabrikadaki iş makinelerinin gürültüsünün çalışanları önemli derecede etkilediğini ve bu konuda önlemler alınması gerektiğini belirtmiştir. Şensögüut ve Çınar (2006, s. 135), gürültüyü etkileyen faktörleri belirleyip gürültüyle ilgili bir denklem oluşturmuşlardır. Tripathy ve Rao (2015) bir boksit madeninde çalışan işçilerin iş makinelerinden ne kadar fazla etkilendiğini ve bu konuda yapılabilecek iyileştirmeleri araştırmıştır. Silva ve Oliveira (2014) şehir planlamasının binaların maruz kaldığı gürültü üzerine etkilerini incelemek amacıyla modeller kurmuştur. Seidler vd. (2017), Frankfurt Uluslararası Havaalanı'na yakın bölgede yaşayanların katılımıyla yaptığı bir araştırmada havayolu, demiryolu ve karayolundaki gürültünün insanlarda depresyona yol açtığını belirlemiştir. Abbaspour vd. (2015, s. 96-99), İran'da yaptığ1 bir araştırmada analitik hiyerarşi prosesi yöntemini kullanarak gürültüyü etkileyen her bir faktörün ağırlı̆ııı hesaplamıştır. Gültekin vd. (2013) İstanbul'daki 5 değişik devlet hastanesinin polikliniklerindeki gürültü düzeylerini incelemiş ve değerlerin sınırların üzerinde olduğunu, önlemler alınması gerektiğini bildirmiştir. Quadros vd. (2014, s. 81-82), Brezilya'da bir hayvanat bahçesinde yaptığı çalışma ile gürültünün sadece insanlar üzerine etkilerinin olmadığını, bundan hayvanların da olumsuz yönde etkilendiğini bize göstermiştir. Görüldüğü gibi gürültü okulun yanı sıra hemen hemen yaşamın her alanında önemli bir problem olarak ele alınmaktadır. Problemin çözümü için toplanan verilerin sistematik bir şekilde ele alınması problemin çözümü konusunda yürütülen çalışmalara önemli katkı sunacaktır. Bu çalışmada okulda gürültü konusunda toplanan verilerin veri madenciliği gibi sistematik bir yaklaşımla analiz edilmeye çalısılımışıtı. Literatür taramasında gürültüyle ilgili toplanan verileri veri madenciliği yaklaşımını kullanarak sistematik bir şekilde analiz eden çalışmaya rastlanmamıştır. Bu nedenle bu çalışmanın literatürdeki bu boşluğu doldurarak, yürütülecek çalışmalara katk1 sağlaması hedeflenmektedir.

Günümüzde gelişen teknoloji ve dolayısıyla artan veri boyutu kurumları farklı alanlara yönlendirmektedir. Büyük ve karışık veriler içinden anlamlı ilişkiler bulunmasına yardımcı olan veri madenciliği bu ihtiyaçlara cevap vermekte ve son yllarda büyük ilgi görmektedir (Han ve Kamber, 2011). Veri madenciliğinde birliktelik kurallarının bulunması için geliştirilen Apriori algoritması yardımıyla veriler arasında ilişkiler bulunabilmektedir (Han ve Kamber, 2011). Örneğin bir marketteki müşterilerin gelir ve eğitim seviyelerinin satınalma davranışlarına etkisi belirlenebilmektedir (Prokeinová ve Paluchová, 2014). Veya bir tur şirketinin müşterilerinin hangi paketleri daha çok seçtiği hakkında bilgi verebilmektedir (Akgün ve Çizel, 2017). Daha farklı alanlarda da apriori algoritması kullanılabilmektedir. Dalkılıç ve Aydın (2017, s. 550-552) yaptığı çalışmada üniversite öğrencilerinin devamsızlık davranışlarını etkileyen faktörleri araştırmıştır. Pehlivanoğlu ve Duru (2016) ise lise ve üniversite öğrencilerinin teknoloji bağımlllı̆ının araştırılması ile ilgili çalışmalar yapmıştır. Literatürde Apriori algoritması kullanılarak bir okuldaki gürültü seviyesinin öğretmenler tarafindan algısının araştırıldığı bir örneğe rastlanmamış olup bu çalışma bu açıdan bir ilk olma özelliği taşımaktadır. Okullardaki gürültü ölçüm verilerini değerlendirmek için bu konuda belirlenmiş ulusal ve uluslararası sınır değerler oldukça önemlidir. WHO (Dünya Sağlık Örgütü)'ne göre okullardaki gürültü seviyesi ders sırasında $35 \mathrm{~dB}(\mathrm{~A})$ 'yı ve teneffüslerde $55 \mathrm{~dB}(\mathrm{~A})$ 'yı geçmemelidir (WHO, 1999).

Ülkemizde bu konu ile ilgili binaların gürültüye karşı korunması hakkında hazırlanan yönetmelik Tablo 1'de gösterilmiştir. Yönetmeliklerdeki sınır değerleri hem okullardaki gürültü ölçümlerinin hem de veri madenciliği çalışması aracılığıyla bulunan anket sonuçlarının yorumlanması açısından önemlidir. 
Tablo 1. Akustik. Simflara Göre Gürültü Simır Değerleri (Çevre ve Şebircilik. Bakanliğ, (2017))

\begin{tabular}{|c|c|c|c|c|c|c|c|c|c|}
\hline \multirow{2}{*}{$\begin{array}{l}B \dot{I} N A \\
\dot{I S S L E V I}\end{array}$} & \multirow{2}{*}{\multicolumn{2}{|c|}{$M E K A N$}} & \multirow{2}{*}{$\begin{array}{c}Z A M A N D \dot{I L I M I} \\
\text { Gece : } 23.00-07.00 \\
\text { Akşam : } 19.00-23.00 \\
\text { Gündüz }: 07.00-19.00\end{array}$} & \multicolumn{6}{|c|}{$\begin{array}{c}\dot{I}_{\text {ç gürüIttü düzeyi, LAeq }} \\
\text { AKUSTIK PERFORMANS SINIFI }\end{array}$} \\
\hline & & & & $\boldsymbol{A}$ & $\boldsymbol{B}$ & $C$ & $D$ & $E$ & $F$ \\
\hline \multirow{3}{*}{$\begin{array}{l}\text { Konut } \\
\text { Binalar1 }\end{array}$} & \multicolumn{2}{|l|}{ Yatak Odalar1 } & Gece & 26 & 30 & 34 & 38 & 42 & 46 \\
\hline & \multicolumn{2}{|l|}{ Yassam Alanları } & 24 saat & 31 & 35 & 39 & 43 & 47 & 51 \\
\hline & \multicolumn{2}{|l|}{ Mutfaklar } & 24 saat & 31 & 35 & 39 & 43 & 47 & 51 \\
\hline \multirow{8}{*}{$\begin{array}{l}\text { Eğitim } \\
\text { Tesisleri }\end{array}$} & \multicolumn{2}{|l|}{ Derslikler } & Gündüz - Akşam & 31 & 35 & 39 & 43 & 47 & 51 \\
\hline & \multicolumn{2}{|l|}{ Özel Derslikler } & Gündüz - Akşam & 36 & 40 & 44 & 48 & 52 & 56 \\
\hline & \multicolumn{2}{|l|}{ İdari Odalar } & Gündüz - Akşam & 31 & 35 & 39 & 43 & 47 & 51 \\
\hline & \multicolumn{2}{|l|}{ Spor Salonu } & Gündüz - Akşam & 41 & 45 & 49 & 53 & 57 & 61 \\
\hline & \multicolumn{2}{|c|}{ Okuma Odaları } & Gündüz - Akşam & 31 & 35 & 39 & 43 & 47 & 51 \\
\hline & \multicolumn{2}{|c|}{ Sirkülasyon Alanları } & Gündüz - Akşam & 41 & 45 & 49 & 53 & 57 & 61 \\
\hline & \multirow[t]{2}{*}{ Kreşler } & $\begin{array}{l}\text { Oyun-yemek } \\
\text { alanlar1 }\end{array}$ & Gündüz & 36 & 40 & 44 & 48 & 52 & 56 \\
\hline & & Yatak odalar1 & Gündüz & 26 & 30 & 34 & 38 & 42 & 46 \\
\hline
\end{tabular}

Yönetmelikte, akustik performans sınıfları A'dan F’ye doğru en iyiden en kötüye olacak şekilde sıralanmıştır:

A sınıfi: Gürültüye karşı yüksek koruma ile sağlanan sessiz bir ortamı,

B sınıfi: Normal koşullarda, kullanıcının sınırlaması gerekmeksizin iyi bir korumayı,

C sınıfi: Kullanıcıların davranışlarının normal sınırca olması durumunda rahatsızlığın fazla olmadığı (aynı zamanda binaların dâhil olması gereken en düşük seviyeyi),

D sınıfi: Kullanıcıların davranışlarının normal sınırda olmasına rağmen genel bir rahatsızlık olduğu ortami,

E sınıfi: Gürültüye karşı düşük koruma sağlanan bir ortam,

F sınıfi: Gürültüye karşı korumasız bir ortamı temsil etmektedirler.

Sınıf içi öğrenme kalitesini etkileyen en önemli faktörlerden olan, insan kulağının duyma alanındaki frekansların ses düzeylerinin ağırlıklı ortalaması (LA, eq) ve bir alandaki sesin kaybolana kadar duvarlardan yansıması sonucu oluşan çınlanımın nasıl hesaplandığı sırasıyla Bölüm 1 ve 2'de verilmiştir.

\section{Gürültü Ölçümünde Kullanılan Parametreler}

Ortalama gürültü düzeyi

$$
L_{\text {Aeq,ort }}=10 \times \log 10 \times \frac{\sum_{i=1}^{n} 10^{\left(\frac{x_{i}}{10}\right)}}{n}
$$

olarak hesaplanmaktadır. (1) denkleminde $x_{i}=30$ sn içinde alınan $i$. örnek, $n$, örnek sayısıdır. $L_{A, 90}$ ise ilgili ölçüm seviyesinin \% 90'ının üzerinde olduğu ses düzeyidir. Bu düzey istatistiki olarak arka plan gürültüsünün ölçümünde kullanılabilmektedir.

\section{2. Çınlanım}

Meissner (2017), çınlanım süresini etkileyen faktörleri belirlemiştir.

Çınlanım süresi; bir hacmin akustik performansının belirlenmesinde kullanılan en önemli kriterlerdendir. İlgili kaynağın susmasından itibaren $60 \mathrm{~dB}$ ’lik düşüş için geçen süredir. Çınlanım süresinin grafik üzerinden hesab1 (RT60) Şekil 1'de gösterilmiştir. 


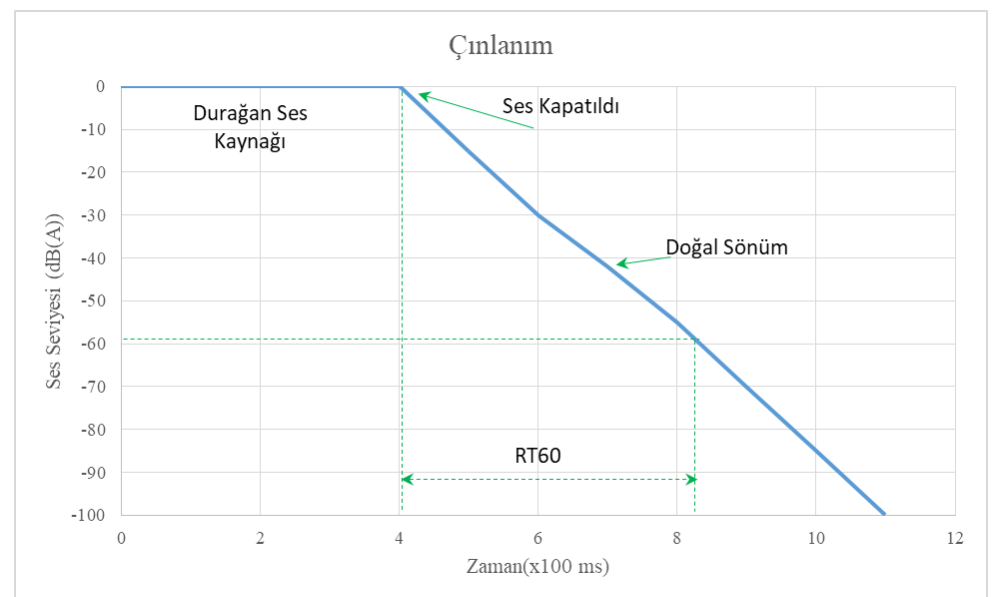

Şekil 1. Çnlanm Süresinin Grafike Üzerinden Hesabı

Çınlanım deneyleri yapilırken arka plan gürültüsünün ölçümleri etkilemeyecek düzeyde olması gerekmektedir. Aksi takdirde sağıklı sonuçlar alınamamaktadır. Ses kaynağı olarak bir tabanca veya balon kullanılabilmektedir. Şekil 2'de bir kaynaktan çıkan sesin bir mikrofona ulaşana kadar yansıdığı alanlar gösterilmiştir.

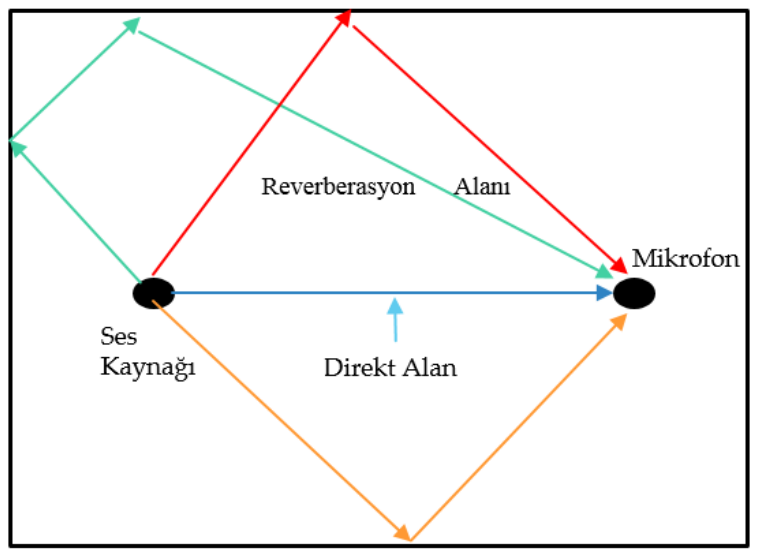

Şekil 2. Sesin Oda İçinde Yansımast

Ölçülmek istenen frekans bandına bağlı olarak çınlanım süresi ölçülecek yerin hacmi değişmektedir. Tablo 2'de görüldüğü üzere frekans bandı arttıkça gerekli olan hacim azalmaktadır.

Tablo 2. Frekans Hacim Illiskisi

\begin{tabular}{cc}
\hline ÖIçülmek istenen en düşük 1/3 oktav frekans band1 & Çınlanım odası için tavsiye edilen en küçük hacim \\
\hline $100 \mathrm{~Hz}$ & $200 \mathrm{~m}^{3}$ \\
$125 \mathrm{~Hz}$ & $150 \mathrm{~m}^{3}$ \\
$160 \mathrm{~Hz}$ & $100 \mathrm{~m}^{3}$ \\
$>200 \mathrm{~Hz}$ & $70 \mathrm{~m}^{3}$ \\
\hline
\end{tabular}

Ülkemizde yayınlanan Binaların Gürültüye Karşı Korunması Hakkında Yönetmeliğe göre akustik performans sınıfına bağlı olarak çeşitli tesislerde olması gereken çınlanım süreleri Tablo 3’te gösterilmiştir. 
Tablo 3. Cinlanım Simır Değerleri

\begin{tabular}{|c|c|c|c|}
\hline Bina İşlevi & \multicolumn{2}{|l|}{ Mekan } & $\begin{array}{c}\text { Akustik Performans Sinifi } \\
\qquad-D(s n)\end{array}$ \\
\hline \multirow{3}{*}{ Konut Binaları } & \multicolumn{2}{|c|}{ Sirkülasyon alanları } & 1,2 \\
\hline & \multicolumn{2}{|c|}{ Yatak odalar1 } & 0,5 \\
\hline & \multicolumn{2}{|c|}{ Yaşam Alanları, Mutfak } & 0,8 \\
\hline \multirow{5}{*}{ Eğitim Tesisleri } & \multicolumn{2}{|c|}{ Derslikler, Özel derslik, İdari odalar, Okuma odaları } & 0,8 \\
\hline & \multicolumn{2}{|c|}{ Spor Salonu } & 1,8 \\
\hline & \multicolumn{2}{|c|}{ Sirkülasyon Alanları } & 1,2 \\
\hline & \multirow{2}{*}{ Kreşler } & Oyun, yemek alanlar1 & 0,8 \\
\hline & & Yatak odaları & 0,5 \\
\hline
\end{tabular}

Burada belirtilen sınır değerler C ve D sınıfları için belirlenmiştir. Bina işlevlerine bağlı olarak diğer sınıflar için gerekli çınlanım sürelerine akustik uzmanların karar vermesi uygun bulunmuştur. Sirkülasyon alanı koridor, giriş holü gibi alanlardır. Özel derslik ise müzik odası, dans odası, resim ve el işi derslikleridir.

$\mathrm{Bu}$ çalısmanın iki amacı vardır. Birincisi okullardaki gürültünün durum analizi, İkincisi ise öğretmenlere ölçüm öncesi dönemde okullarındaki gürültü algılarının araştırılması için yapılan anketler içinden veri madenciliğinin ilişki bulma algoritmalarından Apriori aracıllğıyla bulunması ve bulunan sonuçların okullardaki gürültü düzeyi ile ilişkisinin ortaya konmasıdır.

\section{Yöntem}

\section{Örneklem}

Bu çalışmada 4 okulda (3 Mart Azizoğlu İlköğretim Okulu (3 Mart), Dilek Özer Ortaokulu (Dilek Özer), Sadettin Türkün Ortaokulu (Sadettin Türkün) ve Mustafa Münevver Olağaner İlköğretim Okulu (MMO) önce öğretmenlere gürültü algılarını anlamak amacıyla anketler, sonrasında okullarında gürültü ölçümleri yapılmıştır gerçekleştirilmiştir. Bunun dışındaki okullarda (Hüsnü Züber, Emir Koop İ.O, Özlüce Anadolu Lisesi , Hatice Gani Erverdi Ortaokulu, Ahmet Erdem Anadolu Lisesi, Koç Ortaokulu, Nurettin Topçu İmam Hatip Lisesi, Akşemsettin İ.O, Özel Final Okulları, Özel Tan Okulları, Meral Muammer Ağım Okulu) sadece öğretmen anketleri yapılmıstır.

3 Mart Okulu şehir dışında ama ana yola yakın bulunmakta, diğer 3 okul şehir içinde bulunmaktadır. Okullar trafik gürültüsünden etkilenmektedir. Sadece 3 Mart okulunda orta düzeyde akustik yalıtım bulunmaktadır.

3 Mart'ta 816 öğrenci 34 derslik, Dilek Özer'de 690 öğrenci 24 derslik, Sadettin Türkün'de 804 öğrenci 25 derslik ve MMO'da 1162 öğrenci 19 derslik bulunmaktadır.

Bu bölümde Apriori ile ilgili bilinmesi gereken temel kavramlar, Apriori Algoritması, öğretmenlere yapılan anketler ve gürültü ölçümleri yapılan okullardaki gürültü seviyesi ile ilgili gürültü haritaları verilmiştir.

\section{Temel Kavramlar} için;

Birliktelik kuralları bulunurken destek, güven ve lift değerleri büyük önem taşımaktadır. A=>B kuralı

Destek $(\mathrm{A}=>\mathrm{B})=\mathrm{P}(\mathrm{AUB})$

Güven $(A=>B)=P(B \mid A)^{\prime}$ dir.

$\mathrm{A}=>\mathrm{B}$ kuralının bütün kurallar içinde ne kadar oranda bulunduğunu "A veya $\mathrm{B}$ olaylarının gerçekleşme olasıllı̆ı" ile tanımlanan destek değeri açıklar. Güven ise "A olayının" olması durumunda "B olayının" da gerçekleşmesinin koşullu olasılığını verir. Bu değerler tek başına bir kuralın yaygın olup olmadığı konusunda tam bilgi verememektedir. Bu sebeple aşağıda açıklanan lift değeri de kullanılmaktadır. (Han ve Kamber, 2011)

$$
\operatorname{Lift}(A, B)=\frac{P(A U B)}{P(A) P(B)}
$$


Yukarıdaki denklem ile verilen Lift değeri A ve B olayları arasındaki korelasyonu açıklamaktadır. Bulunan bir kuralın lift değeri 1'den küçük ise A ve B olayları birbirini negatif etkilemektedir. 1'den büyük değerler aralarında pozitif bir korelasyon olduğunu ve böyle bir kuralın yaygın olabileceğini göstermektedir. Eğer 1'e eşit ise A ile B olayları birbirinden bağımsız olaylardır ve aralarında bir korelasyon yoktur. 1'den büyük lift değerleri bulunan kuralı destekler niteliktedir. (Han ve Kamber , 2011)

\section{Apriori Algoritması}

Agrawal ve Srikant tarafindan 1994 yılında bulunan Apriori Algoritması veri madenciliği alanında bulunan en önemli algoritmalardan biridir. Așağıda algoritmanın yapısı pseudo kod olarak verilmiştir (Agrawal ve Srikant, 1994).

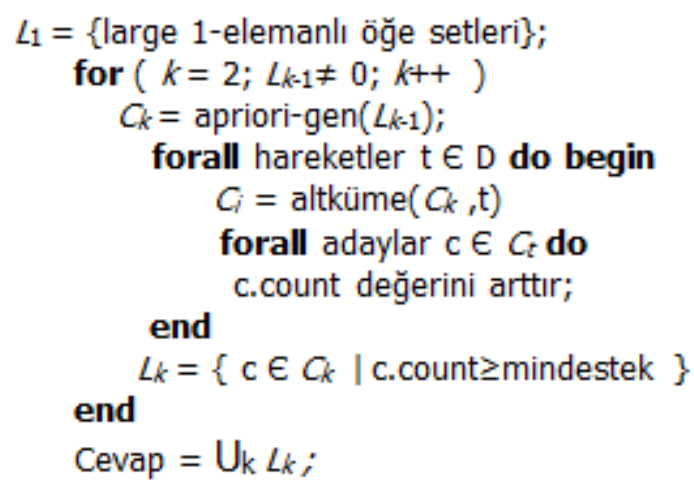

Şekil 3. Apriori algoritması pseudo kodu

Algoritmada s1k geçen öğe kümeleri "L" ile, aday öğe kümeleri "C" ile gösterilmiștir. Temel olarak "k1" elemanlı s1k geçen öğe kümesinden " $\mathrm{k}$ " elemanlı sık geçen öğe kümesi oluşturulur ve bu kümedeki elemanlar kullanıcı tarafindan belirlenen minimum destek değerine göre(minsup) budama işlemine tabi tutulur.(Agrawal ve Srikant, 1994) Şekil 4'de budama işlemini de içeren pseudo kod verilmiştir.

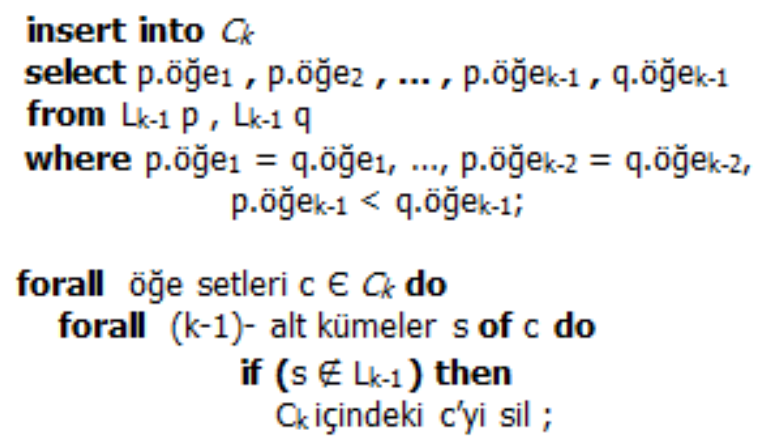

Şekil 4. Apriori-gen fonksiyonunun pseudo kod yapist

Oluşturulan "k elemanlı" aday kümenin içinde "k-1" elemanlı sık geçen öğe kümesinde bulunmayan elemanlar bulunabilir. Bu durumu kontrol etmek ve istenmeyen elemanları silmek için Şekil 3'te geçen “apriori-gen" fonksiyonu kullanılmaktadır. Apriori-gen fonksiyonunun pseudo kodu Şekil 4'te verilmiştir. (Agrawal ve Srikant, 1994)

\section{Gürültü Ölçümleri}

Ölçümler Brüel \& Kjaer Type 2250 frekans analizörü ile yapılmış, analizler için $\mathrm{L}_{\text {Aeq }}$ ve $\mathrm{L}_{A 90}\left(\mathrm{~L}_{A 90}\right.$ sadece arka plan gürültüsünün belirlenmesi için istatistiki olarak) parametreleri kullanılmıştır. Tüm ölçüm noktalarında 30 sn'lik ölçüm zamanı kullanılmıştır. 


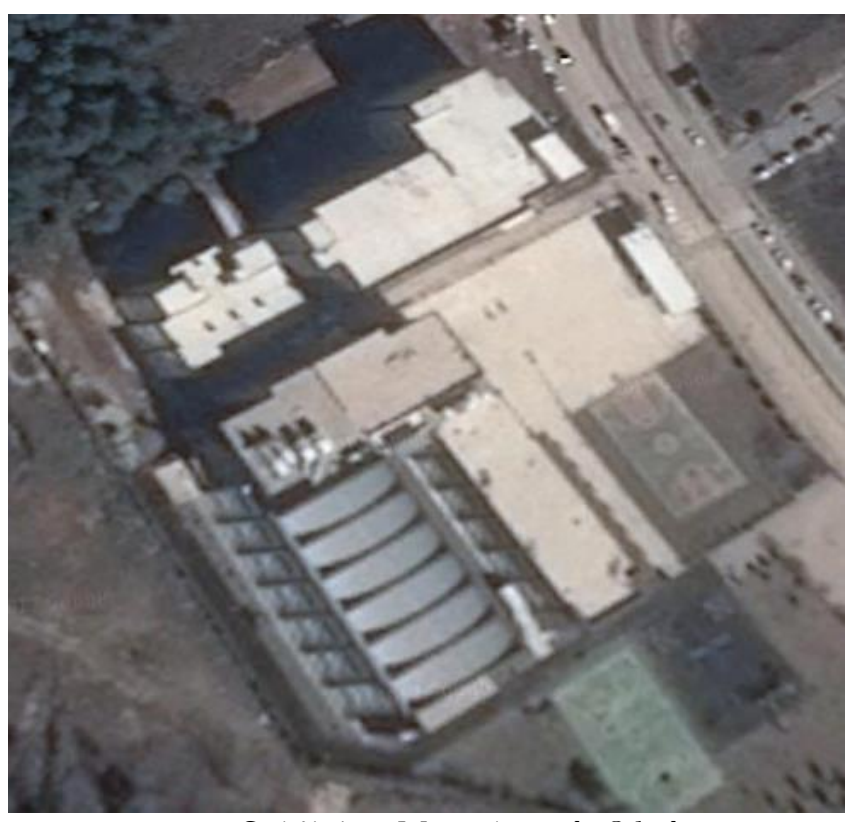

Şekil 5. 3 Mart Ažizoğlu Okulu

Şekil 5, 6, 7 ve 8'de ölçüm yapılan okulların uydu görüntüsü gösterilmiştir.

Ölçümler sırasında yağmur veya şiddetli bir rüzgâr olmamıştır. Yerden yüksekliğin 1,6 m ve duvarlardan uzaklı̆ı̆n en az $1 \mathrm{~m}$ olmasına özen gösterilmiştir. Derste ve teneffüste olmak üzere sınıfta ve koridorda gürültü ölçümleri yapılmıştır.

Sınıflarda yapılan ölçümlerde kapılar ve camlar kapalı konumda olmasına özen gösterilmiştir. Her bir sınıfta 4 köşe noktasında ölçüm yapılarak bunların ortalaması kullanılmıştır.

Çınlanım deneyleri,

1) Sinif ve koridorlarin ortasinda,

2) Yerden 1,6 m yüksekliğinde,

3) Pencere ve kapılar kapalı olacak şekilde,

4) Balon kullanilarak,

5) Hiçbir öğrencinin arka plan gürültüsüne sebep olmaması için okul saatleri dışında yapılmıştır.

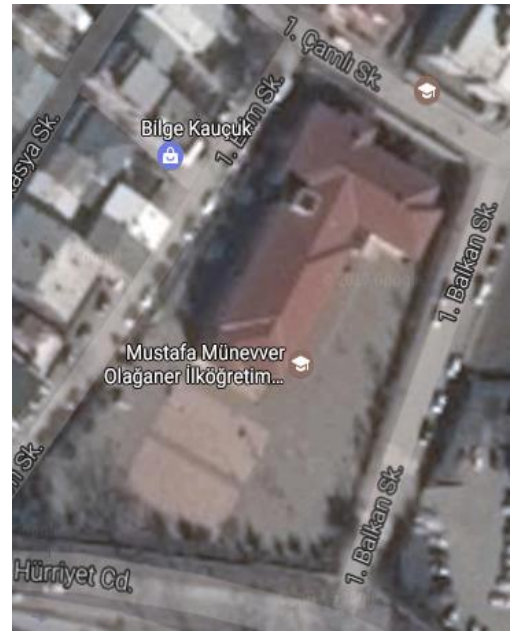

Şekil 6. Mustafa Münevver Olağaner Ilkokulu

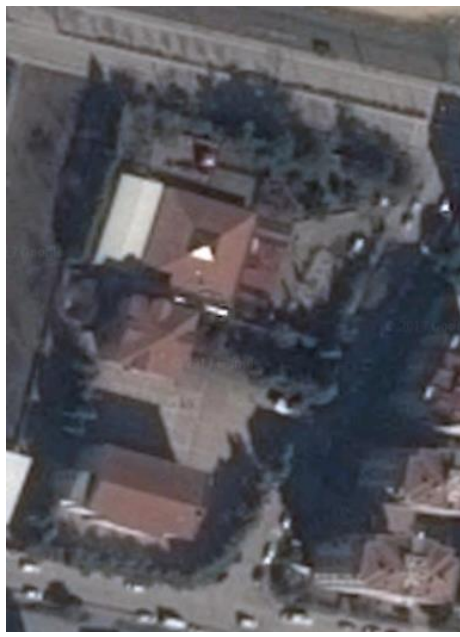

Şekil 7. Dilek Özer Ortaokulu

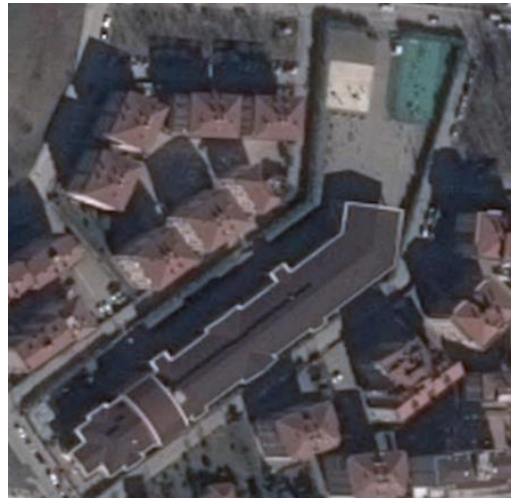

Şekil 8. Sadettin Türkün Ortaokulu 


\section{Verilerin Analizi}

Ders sırasında yapılan ölçümleri içeren gürültü haritaları Şekil 9'da gösterilmiştir. Renkler koyulaştıkça gürültü seviyesi artmaktadır. Gri ve beyaz alanlar ölçüm yapılmayan (tuvalet, müdür odası, bilgi işlem odası gibi) yerlerdir. A, B ve C şekillerindeki haritalar derslerdeki durumu göstermesine rağmen her bir okulun durumu farklıdır. Okullarda ders sırasındaki gürültü seviyesi 40-45 dB(A)'den 80-85 dB(A)'ya kadar yüksek seviyelere ulaşabilmektedir. Ayrıca, ölçümler yapılmadan önce bahsedilen okullardaki öğretmenlerin gürültü düzeyi ile ilgili görüşlerini araştırmak amacıyla anketler ve analizleri yapılmıştır. Öğretmenlere yapılan anketler ile ilgili öznitelikler Tablo 4'de verilmiştir.

Tablo 4. Öænitelikler

\begin{tabular}{ll}
\hline Öznitelikler & Açıklama \\
\hline Okul adı & Okul adlarının tutulduğu 1-15 arasında değer alabilen kategorik değişken: Sadettin Türkün Ortaokulu, Dilek \\
& Özer Ortaokulu, ÇEK, Hüsnü Züber, Emir Koop İ.O, Özlüce Anadolu Lisesi, Hatice Gani Erverdi Ortaokulu, \\
& Ahmet Erdem Anadolu Lisesi, Koç Ortaokulu, Mustafa Münevver Olağaner İ.O, Nurettin Topçu İmam \\
& Hatip Lisesi, Akşemsettin İ.O, Özel Final Okulları, Özel Tan Okulları, Meral Muammer Ağım Okulu \\
Cinsiyet & 1: kadın 2: erkek \\
\hline Kıdem & $\begin{array}{l}\text { Öğretmenlerin tecrübelerini gösterir. } \\
\text { 1: “0-1 yll” ve 5: “16 ve üstü” yıl olacak şekilde 1'den 5’e kadar değer alabilir }\end{array}$ \\
& $\begin{array}{l}\text { 1'den 11’e kadar değer alabilir. } \\
\text { Branş }\end{array}$ \\
& Türkçe, matematik, fen bilgisi, sosyal bilgiler, müzik, beden eğitimi, resim, din ve ahlak bilgisi, İngilizce, sınıf \\
\hline
\end{tabular}

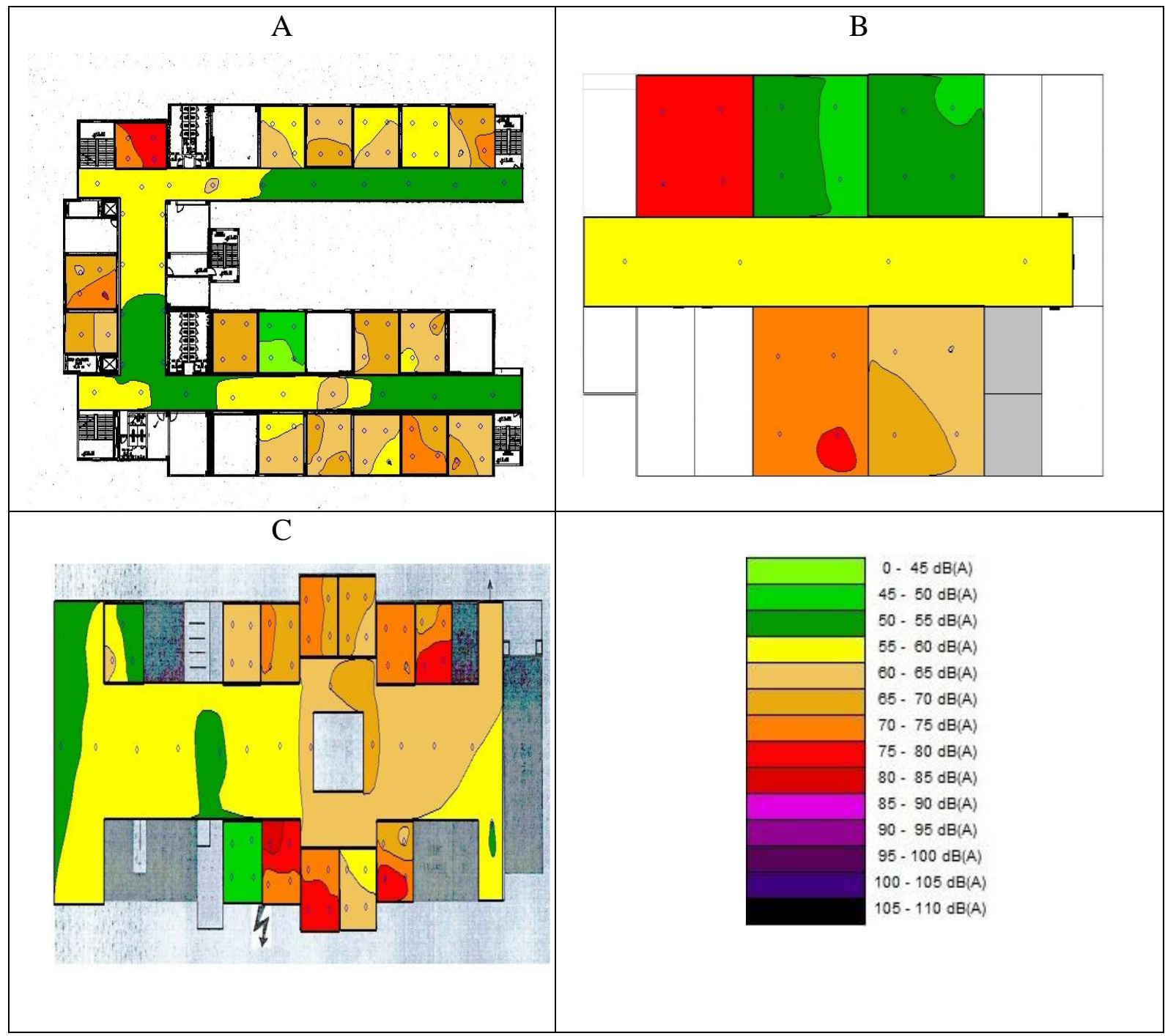

Şekil 9. Gürültü Haritalan 
ORBAK ve AYDIN

Türkiye'de Bir Büyükşehirdeki Okullarda Gürültü Seviyesinin Tespiti ve Öğretmenlerin Görüşlerinin Veri Madenciliği ile Analizi

Bu çalışmada gürültü düzeyi ve azaltılabilirliği ile yakından ilgili olduğu için aşağıdaki 6 soru analizler için kullanılmıştır. Bu sorular ve açılamaları Tablo 5'de gösterilmiştir.

Tablo 5. Anket Sorular

\begin{tabular}{|c|c|c|}
\hline Sorular & Açıklama & Cevap Seçenekleri \\
\hline Pre1 & Genel olarak okulunuzun gürültü düzeyi hakkında ne düşünüyorsunuz? & \multirow{4}{*}{$\begin{array}{l}\text { 1: Çok düşük } \\
\text { 2: Düşük } \\
\text { 3: Orta düzey } \\
\text { 4: Yüksek } \\
\text { 5: Çok yüksek }\end{array}$} \\
\hline Pre3 & Ders sırasında sınıf içi gürültü düzeyi hakkında ne düşünüyorsunuz? & \\
\hline \multirow[t]{2}{*}{ Pre4 } & \multirow[t]{2}{*}{ Teneffüs saatlerinde okul içi gürültü düzeyi hakkında ne düşünüyorsunuz? } & \\
\hline & & \\
\hline \multirow{5}{*}{ Pre19 } & \multirow{5}{*}{$\begin{array}{l}\text { Size göre sınıfın akustik/işitsel koşulları ile öğrencilerin derslerindeki başarısı arasında } \\
\text { nasıl bir ilişki kurulabilir? }\end{array}$} & 1: Hiç ilişki yoktur \\
\hline & & 2: İlişkisizdir \\
\hline & & 3: Biraz ilişkilidir \\
\hline & & 4: İlişkilidir \\
\hline & & 5: Doğrudan ilişkilidir \\
\hline \multirow{4}{*}{ Pre23 } & \multirow{4}{*}{ Okuldaki gürültü düzeyinin azaltılabileceğine inanıyor musunuz? } & $\begin{array}{l}\text { 1: Kesinlikle inanmiyorum } \\
\text { 2: İnanmiyorum }\end{array}$ \\
\hline & & 3: Kararsizim \\
\hline & & 4: İnaniyorum \\
\hline & & 5: Kesinlikle inanıyorum \\
\hline \multirow{5}{*}{ Pre24 } & \multirow{5}{*}{$\begin{array}{l}\text { Sizce okulda gürültüyü önlemek ya da azaltmak eğitim kalitesi açısından ne kadar } \\
\text { önemlidir? }\end{array}$} & 1: Hiç önemli değil \\
\hline & & 2: Önemli değil \\
\hline & & 3: Orta derecede \\
\hline & & 4: Önemli \\
\hline & & 5: Çok önemli \\
\hline
\end{tabular}

\section{Bulgular}

Okullarda gürültü ölçümü sırasında en büyük gürültü nedeni sınıftaki öğrencilerdir. Kapı çarpmaları, öğrencilerin gürültücü davranışları teneffüste ölçülen gürültünün şiddetini arttırmaktadır. Gürültü ölçümleri Tablo 6 ve 7'de gösterilmiştir. Sınıf, koridor ve yemekhanede yapılan çınlanım ölçümleri Tablo 8 'da gösterilmiştir.

Tablo 6. $L_{A, \text { eq }}$ Değerleri

\begin{tabular}{|c|c|c|c|c|c|c|c|c|c|}
\hline & & \multicolumn{4}{|c|}{ Ders Saati } & \multicolumn{4}{|c|}{ Teneffüs } \\
\hline & & \multicolumn{2}{|c|}{ Sinif } & \multicolumn{2}{|c|}{ Koridor } & \multicolumn{2}{|c|}{ Sinif } & \multicolumn{2}{|c|}{ Koridor } \\
\hline & & Ekim & Şubat & Ekim & Şubat & Ekim & Şubat & Ekim & Şubat \\
\hline \multirow{5}{*}{ 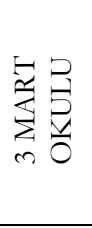 } & Ortalama & 63,35 & 63,38 & 54,013 & 56,51 & 77,02 & 77,48 & 74,9 & 79,06 \\
\hline & sd & 7,66 & 7,93 & 4,799 & 5,89 & 10,68 & 6,23 & 6,49 & 4,23 \\
\hline & $\mathrm{n}$ & 44 & 56 & 38 & 17 & 38 & 28 & 38 & 17 \\
\hline & Min & 51,43 & 46 & 45,98 & 48,66 & 57,56 & 61,92 & 62,64 & 72,01 \\
\hline & Max & 81,26 & 85,88 & 73,3 & 73,3 & 106,31 & 88,79 & 87,11 & 85,97 \\
\hline \multirow{5}{*}{ 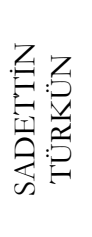 } & Ortalama & 65,809 & 64,37 & 58,29 & 58,53 & 77,52 & 82,07 & 81,24 & 79,53 \\
\hline & sd & 5,442 & 7,23 & 4,64 & 5,02 & 12,6 & 5,03 & 7,07 & 4,47 \\
\hline & $\mathrm{n}$ & 48 & 47 & 16 & 18 & 24 & 24 & 16 & 18 \\
\hline & Min & 56,65 & 45,75 & 50,61 & 49,93 & 59,42 & 74,49 & 64,17 & 68,67 \\
\hline & Max & 78,55 & 74,77 & 69,35 & 67,32 & 106,6 & 94,87 & 89,65 & 85,99 \\
\hline \multirow{5}{*}{ 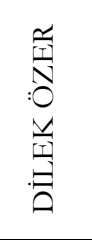 } & Ortalama & 66,6 & 70,73 & 61,351 & 61,631 & 78,12 & 81,11 & 79,17 & 82,33 \\
\hline & sd & 8,1 & 9 & 2,899 & 3,738 & 5,02 & 7,84 & 6,22 & 4,18 \\
\hline & $\mathrm{n}$ & 40 & 24 & 19 & 15 & 20 & 16 & 19 & 15 \\
\hline & Min & 47,65 & 51,86 & 57,55 & 55,75 & 69,37 & 69 & 64,05 & 73,68 \\
\hline & Max & 83,82 & 98,56 & 67,93 & 71,28 & 87,06 & 95,5 & 85 & 89,27 \\
\hline \multirow{5}{*}{$\sum_{i}^{0}$} & Ortalama & 66,995 & 62,993 & 65,81 & 68,24 & 80,13 & 78,738 & 80,33 & 81,751 \\
\hline & sd & 7,629 & 6,978 & 5,65 & 4,11 & 9,24 & 4,721 & 4,29 & 2,848 \\
\hline & $\mathrm{n}$ & 68 & 72 & 12 & 12 & 50 & 36 & 12 & 12 \\
\hline & Min & 50,22 & 47 & 57,01 & 63,03 & 68,07 & 70,08 & 74,36 & 76,73 \\
\hline & Max & 84,69 & 76,43 & 76,21 & 74,8 & 108,61 & 88,14 & 85,57 & 87,43 \\
\hline
\end{tabular}


Tablo 7. Lago Istatistiki Arka Plan Gürültü Değerleri

\begin{tabular}{|c|c|c|c|c|c|}
\hline & & \multicolumn{2}{|c|}{ Ders Saati } & \multicolumn{2}{|c|}{ Teneffüs } \\
\hline & & Sinif & Koridor & Sinif & Koridor \\
\hline \multirow{5}{*}{ 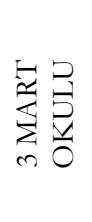 } & Ortalama & 49,77 & 48,68 & 66,86 & 70,04 \\
\hline & sd & 6,29 & 4,00 & 8,98 & 6,21 \\
\hline & $\mathrm{n}$ & 44 & 38 & 38 & 38 \\
\hline & Min & 39,93 & 41,51 & 44,56 & 55,46 \\
\hline & Max & 66,48 & 63,30 & 81,26 & 80,68 \\
\hline \multirow{5}{*}{ 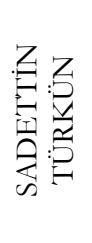 } & Ortalama & 53,03 & 52,42 & 65,31 & 74,26 \\
\hline & sd & 5,25 & 3,65 & 6,09 & 5,71 \\
\hline & $\mathrm{n}$ & 48 & 16 & 24 & 16 \\
\hline & Min & 41,40 & 44,31 & 54,47 & 60,05 \\
\hline & Max & 67,03 & 59,89 & 79,87 & 82,68 \\
\hline \multirow{5}{*}{ 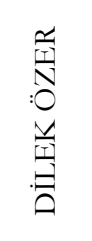 } & Ortalama & 54,75 & 56,30 & 68,50 & 73,20 \\
\hline & $\mathrm{sd}$ & 6,79 & 2,18 & 3,12 & 6,67 \\
\hline & $\mathrm{n}$ & 40 & 19 & 20 & 19 \\
\hline & Min & 41,49 & 52,69 & 64,18 & 58,55 \\
\hline & Max & 66,11 & 59,57 & 75,88 & 80,04 \\
\hline \multirow{5}{*}{$\stackrel{0}{\sum}$} & Ortalama & 54,46 & 59,97 & 67,41 & 72,97 \\
\hline & sd & 6,60 & 5,25 & 7,24 & 5,00 \\
\hline & $\mathrm{n}$ & 68 & 12 & 50 & 12 \\
\hline & Min & 43,27 & 54,08 & 53,81 & 63,54 \\
\hline & Max & 73,47 & 67,98 & 80,43 & 77,62 \\
\hline
\end{tabular}

Tablo 8. Ölçülen Conlanım Değerleri

\begin{tabular}{lccc}
\hline Okul & Sinif & Koridor & Yemekhane/Kantin \\
\hline 3 Mart I.O. & $1,37 \mathrm{~s}$ & $5,67 \mathrm{~s}$ & $5,15 \mathrm{~s}$ \\
MMO I.O. & $2,25 \mathrm{~s}$ & $5,04 \mathrm{~s}$ & $3,96 \mathrm{~s}$ \\
Dilek Özer & $3 \mathrm{~s}$ & $4,5 \mathrm{~s}$ & Yemekhane ve/veya kantin yok \\
Sadettin Türkün & $3 \mathrm{~s}$ & $3,6 \mathrm{~s}$ & $4,5 \mathrm{~s}$ \\
\hline
\end{tabular}

Gürültü ve Çınlanım Sonuçları aşağıda özetlenmiştir:

Çevre ve Șehircilik Bakanlığı'nın binaların gürültüye karșı korunması hakkında 2017 yılında hazırlamıș olduğu yönetmeliğe göre $C$ sınıfı binalar için belirlenen sınır değerler (sınıflar için 0,8 saniye çınlanım 39 $\mathrm{dB}$ gürültü, koridorlar için 1,2 saniye çınlanım $49 \mathrm{~dB}$ gürültü) ile kıyaslandığında bu değerlerin çok üzerindedir $(\mathrm{p}<0,001)$.

Dünya Sağlık Örgütü'nün belirlediği 55 dB'lik gürültü sınırı ile kıyaslandığında sadece 3 Mart Okulu'nda ders saatinde koridorlarda yapılan ölçümler sinır değerdedir $(\mathrm{p}<0,001)$.

Dersliklerde ölçülen çınlanım değerleri kıyaslandığında 3 Mart okulunda daha iyi sonuçlar elde edilmiştir. MMO'daki koridor ve kantinin hacminin 3 Mart Okulu'na kıyasla daha küçük olması çınlanım süresinin daha küçük çıkmasında önemli rol oynamıştır.

Dersliklerin boyutları yakın olduğu için daha sağlıklı bir karşılaştırma yapabilmek adına sınıflarda yapılan çınlanım sürelerinin dikkate alınması durumunda 3 Mart Okulu'ndaki akustik yalıtımın etkili olduğu açıtır.

Ayrıca bu çalışma sonucunda gürültü seviyesinin ölçüm yapılan okula (3 Mart, Sadettin Türkün,Dilek Özer ve MMO), zamana (Ders, Teneffüs), döneme (Ekim 2016, Şubat 2017) ve yere (Sınıf, Koridor) göre değiştiği gözlemlenmiştir.

Onbeş okuldaki öğretmenler ile gürültü ölçümleri öncesi yapılan anketlerden elde edilen kurallar Tablo 9, 10 ve 11'de gösterilmiştir. 
Tablo 9. Tüm Okullardan Elde Edilen Kurallar

\begin{tabular}{lccc}
\hline Kurallar & Destek & Güven & Lift \\
\hline$[1]\{$ cinsiyet $=1, \mathrm{k} 1 \mathrm{dem}=5, \mathrm{pre} 1=5, \mathrm{pre} 24=5\}=>\{$ pre4=5\} & 0,042 & 0,944 & 5,414 \\
{$[2]\{$ cinsiyet=1,pre4=3,pre19=4,pre23 $=3\}=>\{$ pre1=3\}} & 0,042 & 0,944 & 2,034 \\
\hline
\end{tabular}

Tablo 10. Tüm Okullardan Elde Edilen Kurallar (devam)

\begin{tabular}{|c|c|c|c|}
\hline Kurallar & Destek & Güven & Lift \\
\hline$[1]\{$ okulad $1=11$, pre $4=4$, pre $19=5\}=>\{$ pre $23=2\}$ & 0,015 & 1 & 5,152 \\
\hline [2] $\left\{\right.$ okulad $_{1}=11$, pre $3=3$, pre $4=3$, pre $\left.19=4\right\}=>\{$ pre $23=3\}$ & 0,012 & 1 & 4,424 \\
\hline$[3]\{$ branş $=5$, pre $1=3$, pre $23=4\}=>\{$ pre $3=2\}$ & 0,012 & 1 & 3,539 \\
\hline [4] $\{$ cinsiyet $=2, \mathrm{k} 1 \mathrm{dem}=3$, pre $23=4$, pre $24=5\}=>\{$ pre3 $=2\}$ & 0,012 & 1 & 3,539 \\
\hline$[5]\{$ okuladı $=14$, pre $1=3$, pre $19=5$, pre $24=5\}=>\{$ pre $3=2\}$ & 0,012 & 1 & 3,539 \\
\hline$[6]\{$ cinsiyet $=1, \mathrm{k} 1 \mathrm{dem}=4$, pre4=4,pre19=4,pre23=4,pre24=4 $=>\{$ pre3 $=2\}$ & 0,012 & 1 & 3,539 \\
\hline
\end{tabular}

Tablo 10’a bakıldığında [1] nolu kurala göre sınıfın akustik koşulları ile öğrencilerin derslerindeki başarısı arasında doğrudan ilişki olduğunu düşünen ve teneffüs saatlerinde okul içi gürültü düzeyini yüksek düzeyde bulan Nurettin Topçu İmam Hatip Lisesi'ndeki öğretmenlerin hepsi okuldaki gürültü düzeyinin azaltılabileceğine inanmamaktadır. Öte yandan [2] nolu kurala göre sınıfın akustik koşulları ile öğrencilerin derslerindeki başarısı bir ilişski olduğunu düşünen, ders sırasındaki sınıf içi ve teneffüs saatlerinde okul içi gürültü seviyesi orta düzeyde bulan Nurettin Topçu İmam Hatip Lisesi’ndeki öğretmenlerin hepsi okuldaki gürültü seviyesinin azaltılabileceği konusunda kararsız olduklarını belirtmişlerdir. [5] nolu kurala göre sınıfin akustik koşulları ile öğrencilerin derslerindeki başarısı arasında doğrudan ilişki olduğunu ve okulda gürültüyü önlemek ya da azaltmanın eğitim kalitesi açısından çok önemli olduğunu düşünen ve genel olarak okullarının gürültü düzeyini orta düzeyde bulan Özel Tan Okulları öğretmenlerinin hepsi ders sırasında sınıf içi gürültü düzeyini düşük seviyede görmektedir.

Tablo 11. Tüm Okullardan Elde Edilen Kurallar (devam)

\begin{tabular}{|c|c|c|c|}
\hline Kurallar & Destek & Güven & Lift \\
\hline$[1]\{$ pre3 $=5$, pre $4=5\}=>\{$ pre $1=5\}$ & 0,015 & 1 & 9,927 \\
\hline [2] $\{$ okuladı $=12$, pre $4=5$, pre $24=5\}=>\{$ pre $1=5\}$ & 0,012 & 1 & 9,927 \\
\hline$[3]\{$ okulad $1=10$, pre $4=5$, pre $24=5\}=>\{$ pre $1=5\}$ & 0,017 & 1 & 9,927 \\
\hline [4] $\{$ okulad $1=10$, cinsiyet $=1$, pre $3=3\}=>\{$ pre $1=5\}$ & 0,020 & 1 & 9,927 \\
\hline$[5]\{$ k1dem $=5$, pre $3=5$, pre $4=5$, pre $24=5\}=>\{$ pre $1=5\}$ & 0,015 & 1 & 9,927 \\
\hline
\end{tabular}

Tablo 11'e bakıldığında [2] nolu kurala göre teneffüs saatlerinde okul içi gürültü düzeyini yüksek bulan ve okulda gürültüyü önlemek ya da azaltmanın eğitim kalitesi açısından çok önemli olduğunu düşünen Akşemsettin İlköğretim Okulu öğretmenlerinin hepsi genel olarak okullarının gürültü düzeyini çok yüksek olduğunu düşünmektedir. [5] nolu kurala göre 16 ve üzeri yıl tecrübesi olan, ders sırasında sinıf içi ve teneffüs saatlerinde okul içi gürültü düzeylerini çok yüksek bulan öğretmenlerin hepsi okullarının genel gürültü düzeyini çok yüksek bulmaktadır.

Sadece gürültü ölçümlerinin yapıldığı okullardaki öğretmenlere yapılan anketlerin kuralları aşağıdaki tabloda verilmiştir.

Tablo 12. Ölçüm Yapılan Okullardaki Kurallar

\begin{tabular}{|c|c|c|c|}
\hline Kurallar & Destek & Güven & Lift \\
\hline$[1]\{$ okuladı $=2$, cinsiyet $=1\}=>\{$ pre1 $=3\}$ & 0,133 & 0,895 & 2,161 \\
\hline$[2]\{$ okuladı $=1, \mathrm{kıdem}=4\}=>\{$ pre1 $=2\}$ & 0,047 & 0,857 & 1,860 \\
\hline$[3]\{$ cinsiyet $=2, \mathrm{kidem}=4\}=>\{$ pre1 $=2\}$ & 0,047 & 0,857 & 1,860 \\
\hline$[4]\{$ branş $=10, \mathrm{kıdem}=4\}=>\{$ pre $3=2\}$ & 0,047 & 0,857 & 1,503 \\
\hline$[5]\{$ okuladı $=1$, cinsiyet $=1\}=>\{$ pre $3=2\}$ & 0,109 & 0,824 & 1,444 \\
\hline
\end{tabular}

Burada diğer anket analizlerinden farklı olarak 5 seviyeli anket cevapları "1:Düşük, 2:Orta, 3:Yüksek" olacak şekilde değiştirilmiştir. 
Tablo 12'ye bakıldığında [3] numaralı kurala göre 11-15 yıl tecrübesi olan erkek öğretmenlerin \%86's1 okullarının genel gürültü seviyesini orta seviyede görmektedir. [5] nolu kurala göre Sadettin Türkün Ortaokulu'ndaki kadın öğretmenlerin \%82'si ders sırasındaki sınıf içi gürültü düzeyinin orta düzeyde olduğunu düşünmektedir.

\section{Sonuç ve Tartışma}

Öğretmenlerin gürültü algısının araştırıldığı bu çalışmaya göre,

Okullardaki genel gürültü düzeyini çok yüksek bulan, gürültünün azalttllmasının eğitim kalitesi açısından önemini çok yüksek olduğunu düşünen 16 yll ve üzerinde tecrübesi olan kadın öğretmenlerin \%94’ü teneffüs saatlerindeki okul içi gürültü düzeyini çok yüksek bulmaktadır. Ayrıca okuldaki gürültünün azaltılabileceği konusunda kararsız olan, akustik koşullar ile öğrenci başarısı arasında ilişki olduğunu ve teneffüs saatlerindeki okul içi gürültü düzeyini orta seviyede bulan kadın öğretmenlerin \%94'ü okullarındaki genel gürültü düzeyini orta seviyede görmektedir.

Benzer şekilde, ders sırasında sınıf içi ve teneffüs saatlerinde okul içi gürültü düzeylerinin çok yüksek olduğunu düşünen öğretmenlerin hepsi okullarının genel gürültü düzeyinin çok yüksek olduğunu düşünmektedir. MMO okulundaki teneffüs saatlerinde okul içi gürültü düzeyinin çok yüksek olduğunu ve gürültüyü azaltmanın eğitim kalitesi açından çok önemli olduğunu düşünen öğretmenlerin hepsi okullarındaki genel gürültü düzeyini yüksek görmektedirler( $>55 \mathrm{dBA})$. Diğer yandan MMO okulundaki ders sırasındaki sınıf içi gürültü düzeyini orta seviye olarak gören kadın öğretmenlerin hepsi okullarındaki genel gürültü düzeyini çok yüksek olarak görmektedir. MMO okulundaki öğretmenlerin ders sırasındaki sınıf içi gürültü düzeyi ile ilgili farklı görüşleri olsa da okulun genel gürültüsü ile ilgili ortak bir görüşe sahip olduğu görülmüştür.

Öte yandan, okullarındaki genel gürültü düzeyini orta seviyede gören ve gürültünün azaltılabileceğine inanan sosyal bilgiler öğretmenlerinin hepsi ders sırasında sınıf içi gürültü düzeyinin düşük olduğunu düşünmektedir. Buna göre sosyal bilgiler öğretmenleri asıl gürültünün teneffüslerde oluştuğunu, bunun zamanla düzeltilebilecek bir durum olduğunu düşünmektedir. İlginç bir şekilde, 6-10 y1llık tecrübesi olan, okuldaki gürültü düzeyinin azaltılabileceğine inanan ve aynı zamanda gürültüyü önlemenin eğitim kalitesi açısından çok önemli olduğunu düşünen erkek öğretmenlerin hepsi ders sırasında sınıf içi gürültü düzeyinin düşük olduğunu düşünmektedir. Benzer şekilde, 11-15 yil tecrübesi olan teneffüs saatlerinde okul içi gürültüyü yüksek, okuldaki gürültünün azaltılabileceğine inanan, akustik koşulların öğrencilerin başarısı üzerinde etkisi olduğunu düşünen kadın öğretmenlerin hepsi sınıf içi gürültü düzeyinin düşük olduğunu düşünmektedir. Bu bize okuldaki gürültünün azaltılabileceğine inanan hem kadın hem de erkek öğretmenlerin sınıf içi gürültü ile ilgili bir ortak görüşte toplandığını göstermektedir.

Ölçüm yapılan bir diğer okul olan Dilek Özer Ortaokulundaki kadın öğretmenlerin \%90’1 okullarındaki genel gürültü düzeyini çok yüksek bulmaktadır. Yönetmeliklerde belirlenen $55 \mathrm{dBA}$ gürültü seviyesinin sınırının üzerinde bir ses düzeyi olduğu düşünüldügünde bu görüş ölçümleri destekler niteliktedir. Sadettin Türkün okulunda ise 11-15 yll tecrübesi olan öğretmenlerin \%85’i okullarındaki genel gürültü düzeyini orta seviyede görmektedir. Benzer şekilde 11-15 yll tecrübeli İngilizce öğretmenlerinin \%86'sı ders sırasındaki sınıf gürültü düzeyini orta seviyede görmektedir. Bunlar ilginç durumlardır çünkü bu okuldaki gürültü analizlerine bakıldığında $(>55 \mathrm{~dB}(\mathrm{~A}))$ gürültünün diğer okullardan farklı olmadığı ama 11-15 yıllık tecrübesi olan öğretmenlerin gürültüyü kanıksadığını göstermektedir.

Gürültü ölçümü yapılan okullardaki öğretmenlerin anketlerinin analizinden elde edilen sonuçlar ile gürültü ölçümü yapılmayan okullardaki öğretmenlerin anketlerinin analizine göre, öğretmenlerin aynı şeyleri düşündüğü görülmüsstür. Ayrıca okullar arasında bir fark olmadığı ve bütün öğretmenlerin gürültü konusunda rahatsızlikları olduğu saptanmıştır.

Okullarda akustik yalıtım son zamanlarda dikkate alınmaya başlanan bir problem olup üzerinde çalş̧ılması gereken birçok değişkene sahiptir. Gürültü kirliliğini önleme yolları, okulların inşaatı sırasında düşünülmesi gereken önemli bir konudur. Okulların inşasından sonra yapılacak iyileştirmeler daha maliyetli olmaktadır.

Literatürde veri madenciliği yaklaşımlarından Apriori algoritması kullanılarak bir okuldaki gürültü seviyesinin öğretmenler tarafindan algısının araştırıldığı bir örneğe rastlanmamış olup bu çalışma bu açıdan bir ilk olma özelliği taşımaktadır. Bu nedenle bu çalışmanın literatürdeki bu boşluğu doldurarak, yürütülecek çalışmalara katkı sağlayacağ1 düşünülmektedir. 


\section{Öneriler}

Gürültü ve gürültü kirliliği olgusu öğretmenler tarafindan derslerde etkin olarak üzerinde durulmas1 gereken bir konudur. Her öğretmen, özellikle de anaokulu ve sınıf öğretmenleri daha küçük sınıflardan itibaren gürültü yapmamayı, gürültücü davranışlardan uzak durmayı sınıf kuralı olarak belirlemeli ve uygulanması konusunda hassasiyet göstermelidir. Öğretmenler öğrencileri bu konuyu sınıfta uyulması gereken bir kural olarak belirlemeleri konusunda yönlendirmeli ve bu kuralın sinıfta uygulanıp uygulanmadığını yine öğrencilerin takip etmesi konusunda rehberlik etmelidirler. Öğretmenler sessiz bir sınıf / okul iklimi oluşturmak, sınıflarında gürültücü davranışları önlemek ve sükûnetli bir ortam yaratmak konusunda rol model olmalıdırlar. Bu konuda inisiyatif almalıdırlar. Öğrencilerine bağırmadan konuşmalıdırlar. Öğrencilerinin de birbirlerine bağırmadan konuşmaları konusunda gerekli uyarlarda bulunmalidirlar.

Veli toplantılannda gürültü konusunda aileleri bilinçlendirmelidirler. Bu konuda ailelerden de aktif destek alabilmelidirler. Gürültü ve gürültü kirliliği konusunda veliler için broşür / bilgilendirme notu hazırlamalıdırlar.

Bunlara ek olarak bina içi akustik yalıtım yapılmalıdır. Örneğin akustik baffle, akustik pvc zemin kaplamaları ve akustik kumaş kaplı paneller kullanılabilir.

\section{Teşekkür}

Bu çalşma, TÜBİTAK tarafindan desteklenen 114K738 nolu "Okulda Gürültü Kirliliği: Nedenleri, Etkileri ve Kontrol Edilmesi” projesi kapsamında gerçekleştirilmiştir.

\section{Etik Beyan}

'Türkiyye'de Bir Büyüksehehirdeki Okullarda Gürültü Sevijesinin Tespiti ve Öğretmenlerin Görïslerinin Veri Madencilï̈i ile Analiz̨i" başlıklı çalışma TÜBİTAK tarafından desteklenen 114K738 nolu "Okulda Gürültü Kirliliği: Nedenleri, Etkileri ve Kontrol Edilmesi” projesi kapsamında gerçekleştirilmiştir. Gerekli olan etik kurul izinleri Bursa Uludağ Üniversitesi Tip Fakültesi Klinik Araştırmalar Etik Kurulu'nun 04.03.2014 tarih ve 2014-5 sayılı toplantısında 3 numaralı karar olarak alınmıştır. Ayııca Bursa Valiliği İl Milli Eğitim Müdürlüğ̈̈'nün 24.12.2013 tarih ve 3982794 sayll yazısı ile projenin ilk ve orta dereceli okullarda yürütülmesi için gerekli izin ve destek verilmiştir. Makalenin yazım sürecinde bilimsel, etik ve alıntı kurallarına uyulmuş; toplanan veriler üzerinde herhangi bir tahrifat yapılmamış ve bu çalışma herhangi başka bir akademik yayın ortamına değerlendirme için gönderilmemiştir.

\section{Kaynakça}

Abbaspour, M., Karimi, E., Nassiri, P., Monazzam, M. R. ve Taghavi, L. (2015). Hierarchal assessment of noise pollution in urban areas - A case study. Transportation Research Part D, 34, 95-103. http://dx.doi.org/10.1016/j.trd.2014.10.002.

Agrawal, R. ve Srikant, R., (1994). Fast algorithms for mining association rules. Proceedings of the 20th VLDB Conference, Santiago, Chile.

Akgün, A. ve Çizel, B., (2017). Günlük tur programları oluşturmada veri madenciliği: A grubu seyahat acentası örneği. Turiz̧m ve Araştırma Dergisi, 6(1), 73-85. http://dergipark.gov.tr/download/article-file/423846 adresinden 19 Mayıs 2018 tarihinde erişilmiştir.

Aktürk , N., Akdemir, O. ve Üzkurt, İ., (2003). Trafik 1şık sürelerinin neden olduğu çevresel taşıt gürültüsü. Gazi Üniversitesi Mühendislik. Mimarlle Fakültesi Dergisi, 18(1), 71-87. http://dergipark.gov.tr/download/articlefile/76214 adresinden 6 Kasım 2018 tarihinde erişilmiştir.

Berlyne, D. E. (1960). Conflict, arousal and curiosity. New York: McGraw-Hill.

Boateng, C. A. ve Amedofu, G. K. (2004). Industrial noise pollution and its effects on the hearing capabilities of workers : A study from saw mills, printing presses and corn mills. African Journal of Health Services, 11(1-2), 55-60. doi: 10.4314/ajhs.v11i1.30778.

Bowers, J.H. Burkett, C.W. (1987). Relationship of student achievement and characteristics in two selected school facility environmental setting. ERIC No: ED286278.

Bulunuz, N. (2014). Noise pollution in turkish elementary schools: Evaluation of noise pollution awareness and sensivity training. International Journal of Environmental and Science Education, 9(2), 345-360.

Bulunuz, N., Bulunuz, M., Orbak, Y., Mutlu, N. ve Tavsanl, Ö. F. (2017). An evaluation of primary school students' views about noise levels in school. International Electronic Journal of Elementary Education, 9(4), 725-740.

Cohen, S., Evans, G. W., Krantz, D. S., \& Stokols, D. , (1980). Physiological, motivational, and cognitiveeffects of aircraft noise on children. American Psychologist, 35, 231-243.

Çevre ve Şehircilik Bakanlığı, (2017). Binaların gürültüye karşı korunması hakkında yönetmelik. Resmi Gaz̧ete. Say1: 30082. Ankara. 
Dalkılıç, F. ve Aydın, Ö., (2017). Dokuz Eylül Üniversitesi İktisadi ve İdari Bilimler Fakültesi öğrencilerinin devamsızlık davranışlarını etkileyen faktörler. Yükseköğretim ve Bilim Dergisi, 7(3), 546-553. doi: 10.5961/jhes.2017.231.

Glass, D. ve Singer, J. (1972). Urban stress: Experiments on noise and social stressors. New York: Academic Press.

Gültekin, E., Develioğlu, Ö. N., Yener, M., Şenay, N. ve Külekçi, M., (2013). İstanbul/Türkiye’deki değişik hastane polikliniklerinde gürültü kirliliği. Türk Otolarengoloji Arşivi, 51, 101-105. doi:10.5152/tao.2013.1300.

Han, J. and Kamber, M. (2011) Data Mining: Concepts and Techniques. 3rd Edition, Morgan Kaufmann, Burlington.

Hardiman, M. M. (2003). Connecting brain research with effective teaching: The brain targeted teaching model. Lanham, MD: Scarecrow Education.

Hebb, D. O. (1955). Drives and the CNS (conceptual nervous system). Psychological Review, 62, 243-254.

Hockey, G. R. J. (1970). Effects of loud noise on attentional selectivity. Quarterly Journal of Experimental Psychology, 22, 28-36.

Kryter, K. D. (1950). The effects of noise on man. Journal of Speech Disturbance.

McCelland, D. C., Atkinson, J. W., Clark, R. A. ve Lowell, E. L. (1953). The achievement motive. New York: AppletonCentury-Crofts.

Meissner, M. (2017). Acoustics of small rectangular rooms: Analytical and numerical determination of reverberation parameters. Applied Acoustics, 120,111-119. https://doi.org/10.1016/j.apacoust.2017.01.020.

Merchan, C. I., Balteiro, L. D. ve Solino, M. (2014). Noise pollution in national parks: Soundscape and economic valuation. Landscape and Urban Planning, 123, 1-9. doi: http://dx.doi.org/10.1016/j.landurbplan.2013.11.006

Özbiçakçı, Ş., Çapık, C., Aydoğdu, N., Ersin, F. ve Kıssal, A. (2012). Bir okul toplumunda gürültü düzeyi tanılaması ve duyarlilık eğitimi. Egitim ve Bilim, 37(165), 223-236.

Polat, S. ve Buluş-Kırıkkaya, E. (2004). Gürültünün eğitim öğretim ortamına etkileri. XIII. Ulusal Eğitim Bilimleri Kurultayz. İnönü Üniversitesi, Eğitim Fakültesi.

Pehlivanoğlu, M. K. ve Duru, N. (2016). Analysis of technology addiction of high school and university students using data mining techniques. The Eurasia Proceedings of Educational \& Social Sciences, May 19-22, Bodrum, Turkey.

Prokeinová, R. B. ve Paluchová, J., (2014). Identification of the patterns behavior consumptions by using chosen tools of data mining - association rules. Agris on-line Papers in Economics and Informatics, 6(3), 1-12. https://ageconsearch.umn.edu/bitstream/188731/2/agris_on-line_2014_3_benda-prokeinova_paluchova.pdf adresinden 18 Ekim 2018 tarihinde erişilmiştir.

Quadros, S., Goulart, V. D. L., Passos, L., Vecci, M. A. M. ve Young, R. J. (2014). Zoo visitor effect on mammal behaviour: Does noise matter?. Applied Animal Behaviour Science, 156, 78-84. http://dx.doi.org/10.1016/j.applanim.2014.04.002.

Sarantopoulos, G., Lykoudis, S. ve Kassomenos, P. (2014). Noise levels in primary schools of medium sized city in Greece. Science of the Total Environment, 482, 493-500. doi: http://dx.doi.org/10.1016/j.scitotenv.2013.09.010.

Seidler, A., Hegewald, J., Seidler, A. L., Schubert, M., Wagner, M., Dröge, P., ... Zeeb, H. (2017). Association between aircraft, road and railway traffic noise and depression in a large case-control study based on secondary data. Environmental Research, 152, 263-271. http://dx.doi.org/10.1016/j.envres.2016.10.017.

Silva, L. T., Oliveira, M. ve Silva, J. F. (2014). Urban form indicators as proxy on the noise exposure of buildings. Applied Acoustics, 76, 366-376. http://dx.doi.org/10.1016/j.apacoust.2013.07.027.

Strauss, A. A. ve Lehtinen, L. E. (1947). Psychopathology and education of the brain injured child. New York: Grune and Stratton.

Şensöğüt, C. ve Çınar, İ., (2006). Çevresel faktörlerin gürültü yay1lımına etkisi. Dumlupınar Üniversitesi Fen Bilimleri Enstitüsü Dergisi, 10, 131-138. http://dergipark.gov.tr/dpufbed/issue/36179/407502 adresinden 19 Ocak 2019 tarihinde erişilmiştir.

Tamer-Bayazıt, N., Küçükçifçi, S. ve Şan, B. (2011). İlköğretim okullarında gürültüden rahatsızlığın alan çalışmalarına bağlı olarak saptanması. İTÜ Dergisi, 10(2), 169-181.

Tripathy, D. P. ve Rao, D. S. (2015). Noise measurement in a mechanized opencast bauxite mine: A case study. Noise \& Vibration Worldwide, 46(11), 9-19. https://doi.org/10.1260/0957-4565.46.11.9

Tüzel, S. (2013). Sınıf içi gürültünün öğrencilerin dinleme sürecindeki bilişsel performansina etkisi. Eğitimde Kuram ve Uygulama, 9(4), 363-378.

Vasilyev, A. (2017). New methods and approaches to acoustic monitoring and noise mapping of urban territories and experience of it approbation in conditions of Samara region of Russia. Procedia Engineering, 176, 669-674 doi: 10.1016/j.proeng.2017.02.311.

World Health Organisation (1999). Guidelines for Community Noise.

Yassin, M. F., Almutairi, H., Alhajeri, N., Al-Fadhli, F., Al Rashidi, M. S. ve Shatti, T. (2016). Assessment of noise exposure and associated health risk in school environment. Int. J. Environ. Sci. Tecbnol, 13, 2011-2024. doi: 10.1007/s13762-016-1035-y.

Zannin, P. H. T., Engel, M. S., Fiedler, P. E. K. ve Bunn, F. (2013). Characterization of environmental noise based on noise measurements, noise mapping and interviews: A case study at a university campus in Brazil. Cities, 31, 317-327. doi: http://dx.doi.org/10.1016/j.cities.2012.09.008. 


\section{EXTENDED ABSTRACT}

Noise level is one of the main parameters affecting the quality of education of a school. The noise affects both the performance and the health of the students, teachers, administrators, etc. negatively. In addition, what is generally ignored is that to what extent is the school climate is appropriate for educationtraining. The school climate is defined as the whole of the factors that affect the attitudes and behaviors of teachers and students. Free from any doubt, the major role in creating the climate and the culture at schools belong to the administrators and teachers of the school. A healthy school climate provides a learning environment that supports academic, mental and behavioral developments of children. Noise pollution is defined as, the various disrupting and distracting noises that affect physiological and psychological health negatively; avoiding hearing the sounds intended to be heard in the physical space. The high level of noise pollution at school ruins the climate of school affecting the behaviors of teachers and students. According to the regulation made by the Ministry of Environment and Urbanization (Republic of Turkey Ministry of Environment and Urbanization, 2017) buildings were classified from class $\mathrm{F}$ up to A depending on their acoustics qualities. Also for the first time in regulations, reverberation time was bounded, i.e., 0.8 seconds for classes and 1.2 seconds for corridors. For class $\mathrm{C}$, which is the lowest level that buildings need to include, limits were set $49 \mathrm{~dB}(\mathrm{~A})$ in class and $39 \mathrm{~dB}(\mathrm{~A})$ in corridors. Republic of Turkey Ministry of Environment and Urbanization, 2017). Unfortunately, in our country, the level of noise and reverberation time at schools are far above these limits. There are two aims of this research. First one is measuring the noise level and reverberation time of schools. In addition, this study includes an analysis of the duration of reverberation, and measurements of the noise level in schools located in Bursa. Besides, in the study, it was aimed to compare the noise level measured at the school, the duration of reverberation and the level of noise during class time with the limits determined by regulations for Class $\mathrm{C}$ educational buildings set forth by the Ministry of Environment and Urban Planning in 2017. The second aim of the research is determined as the examination of school teachers' views about the noise pollution at schools. This examination was made by data mining. In the research, teachers were classified according to school name, gender, experience and field of study. As it can be seen from the methodology of the research, it is shown that the teachers expressed opinions about the noise pollution at school, its effects and reasons, under 6 questions. These questions are as below "the views about the general noise level in school", "the views about the classroom noise level during course hours", "the views about the noise level during breaks in school", "the relationship between classroom acoustical conditions and academic success of students", "the belief that reducibility of school noise level" and "importance of reducing the noise level in schools for quality of education". 94 percent of 16 years or more experienced female teachers who think that reducing the noise level is very important for the quality of education, also who think that general noise level of school is very high, considered that the noise level in school during breaks was very high. Besides, 94 percent of female teachers who are indecisive about reducibility of school noise level, also who believe that there is a relationship between acoustical conditions and academic success of students, and who states that the noise level in school during breaks was very high, phrased that general noise level of school is medium. Similarly, teachers who tell that noise levels are very high during breaks in school and during course hours in classroom expressed that the general noise level of their schools is very high. MMO school teachers who think that noise level in school during the break is very high and also say reducing the noise level is very important for the quality of education during course hours in classroom declared that general noise level of their schools is very high $(>55 \mathrm{dBA})$. On the other hand, social studies teachers who tell that general noise levels in their schools are medium and also think that noise level can be reduced, conceived that the noise level during course hours in the classroom is low. Finally, through studies performed especially in developed countries, it is indicated that the level of noise pollution both with acoustic precautions and creating awareness of a tranquil learning environment and school culture is formed. However, studies in our country point out that the level of noise that occurred in our schools is far above the limits. It is advised that in order to increase the academic success of students and the teaching performance of teachers, research and development studies that handle noise problem at school with all aspects should be implemented. 